Article title: Implementing Continuous Assessment in an Academic Programme for More Effective Learning Authors: Cecilia van Zyl[1], Willie le Roux[2]

Affiliations: Department of Economics, University of South Africa, City of Tshwane, South Africa[1]

Orcid ids: 0000-0002-6504-4202[1], 0000-0002-3031-2027[2]

Contact e-mail: vzylcj@unisa.ac.za

License information: This work has been published open access under Creative Commons Attribution License http://creativecommons.org/licenses/by/4.0/, which permits unrestricted use, distribution, and reproduction in any medium, provided the original work is properly cited. Conditions, terms of use and publishing policy can be found at https://www.scienceopen.com/.

Preprint statement: This article is a preprint and has not been peer-reviewed, under consideration and submitted to UnisaRxiv for open peer review.

DOI: 10.25159/UnisaRxiv/000006.v1

Preprint first posted online: 22 May 2021

Keywords: continuous assessment, assessment for learning, assessment of learning, assessment as learning, feedback, feedforward 


\title{
Implementing Continuous Assessment in an Academic Programme for More Effective Learning
}

\author{
Cecilia J. van Zyl \\ https://orcid.org/0000-0002-6504-4202 \\ Department of Economics, University of \\ South Africa \\ vzylcj@unisa.ac.za
}

\author{
Willem J. le Roux \\ https://orcid.org/0000-0002-3031-2027 \\ Department of Economics, University of \\ South Africa
}

\begin{abstract}
Many universities, including open distance education institutions, are currently investigating the introduction of a continuous assessment framework. When introducing continuous assessment in an academic department, it is necessary to ensure that all participants understand all concepts related to such framework and the implications of introducing such a framework. This paper investigates studies on continuous assessment in the literature to identify the advantages and disadvantages of such a framework. The lessons learned are used to identify guidelines regarding the importance of feedback and to develop a model that can be used to plan and introduce continuous assessment, considering all the different environmental factors that will affect the introduction.
\end{abstract}

Keywords: continuous assessment, assessment for learning, assessment of learning, assessment as learning, feedback, feedforward

\section{Introduction}

A continuous assessment (CA) system implies that students are assessed regularly throughout the learning period. CA provides the opportunity to receive feedback on a student's progress with regard to learning goals and to change behaviour, if necessary. Before the introduction of CA, the assessment plan at most institutions was rigid and the final mark of a student was usually based on a year mark or semester mark that counted a smaller percentage of the final mark, and a final examination that contributed the majority of the final mark. CA provides much more freedom with regard to the design of the assessment plan.

To ensure that the introduction of CA will still comply with all assessment requirements, while also contributing to more effective learning, it is necessary to carefully consider the reasons for, and advantages of, implementing CA, and also the potential challenges and the disadvantages related to the implementation of CA. The following section discusses the reasons for assessment in general, and also the potential advantages of CA. Then the literature related to the implementation of CA is evaluated with the aim to identify issues that are important to consider when introducing CA in an academic 
department. Feedback to assessment is identified as an essential part of a CA framework, and is next discussed. An overview of challenges that may be experienced when introducing CA is provided. Finally, based on the lessons learned from the literature, a suitable model for the introduction of CA is proposed.

\section{Reasons for Implementing Continuous Assessment}

To understand the reasons for implementing CA, we first have to understand the reasons for having assessment. This is discussed below, followed by a discussion of the potential advantages of using a CA framework and how and why it can be expected to contribute to more effective learning.

\section{Reasons for Assessment}

Hatt $(2019,221)$ distinguishes between assessment for learning and assessment of learning. Assessment for learning refers to assessment tasks that are formative and help students to actively assess what they have learned, to determine what they know and can do, and to identify gaps in their learning that have to be redressed (Russel et al. 2006). Assessment of learning is usually associated with summative assessment and measures what a student has learned. Summative assessment can also contribute to learning, as it provides motivation to students to ensure that they accomplish learning (Baird et al. 2017, 337).

In a CA system, assessment can also form part of the learning process, so we can also refer to assessment as learning (Bjælde and Lindberg 2018, 53). In the environment in which we live where all knowledge is available on the internet, it no longer makes sense to expect students to learn knowledge off by heart. Rather they should have the ability to find relevant information, to be able to apply this to new situations, and to use it for analysis and evaluation. The only way in which such skills can be taught is by doing this, and then receiving feedback on performance. Assessment as learning forms part of formative assessment, as indicated in Figure 1.

Pocock $(2012,7)$ investigated the reason why students do not complete their qualifications at an Engineering faculty in South Africa, and found that 26 per cent of the students indicated that they found the workload too hard or the material too difficult. A total of 15 per cent of the students indicated that they left because of the uncaring attitude of lecturers or a lack of interaction. This implies that more effective teaching methods and engagement with students can contribute to higher retention rates at universities and institutions of higher learning.

A CA framework implies that students are assessed regularly, and this can help to identify at-risk students early in a study period and to redress learning gaps quickly. Students only become aware whether they have achieved the objectives of their studies when they start doing an assessment (Thorpe 1998, 266). 


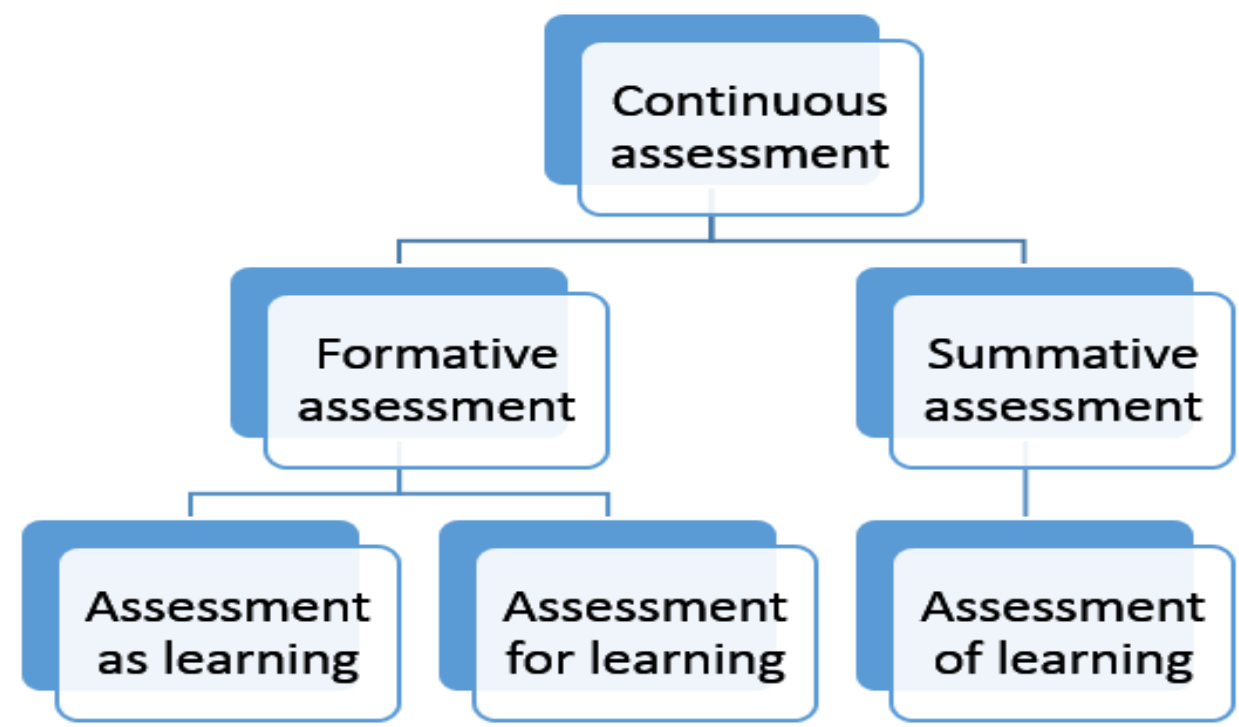

Figure 1: Different types of assessment

\section{Potential Advantages of Implementing Continuous Assessment}

Cook, Butler and Jordan (2013) found that the introduction of a CA system resulted in earlier engagement with study material. If assessment mainly consists of a final summative assessment opportunity, students are inclined to cram their studies into a short period before the assessment takes place (Lovatt, Finlayson, and James 2007), resulting in superficial learning. Deep learning depends not on the student, but on the situation (Ramsden 2003, 49). If opportunities are created and the student engage in such opportunities, deep learning will take place, and therefore well-designed CA can contribute to more effective learning.

In a CA framework, there is room for students to provide feedback on their own work (self-assessment) and on the work of fellow students (peer assessment). A CA system may thus also be used to help students to become self-reflective learners and develop the ability to provide constructive criticism. Both these skills are important in most professions.

CA may reduce the anxiety that results from once-off summative assessments. A welldesigned CA system that places less importance on individual assessments may even help students to learn to handle stressful situations better, as smaller assessment tasks may give them the confidence that they can be successful.

Given the fourth industrial revolution, students should no longer only engage with study material that is provided to them, but should also be taught to find relative information, 
to connect information from different sources, and to create new knowledge that can be shared (Siemens 2005). CA allows lecturers and students to engage with each other regularly, and this process in itself can, and should, be knowledge creating. Such engagement teaches students the way in which the world now works, and will prepare them for their future professions in a way in which one final summative assessment definitely cannot do.

Finally, a CA framework also provides information that lecturers can use to adjust and improve their teaching methods timeously, and in this way contribute to more effective learning by students.

\section{Overview of Studies with regard to the Implementation of Continuous}

\section{Assessment}

The environment in which each institution operate is unique and will affect the successful implementation of CA.

Hernández (2012) investigated the views and perceptions of students and lecturers with regard to CA at eight universities in Dublin. She focused on the extent to which student learning can be facilitated through "forward" feedback. Forward feedback or "feedforward" implies that students understand exactly what will be expected from them during assessment and increases their motivation for learning.

The introduction of feedback loops to CA by Bjælde and Lindberg (2018) also builds on the "feedforward" theme, but adds an important dimension in the form of student support through the collection of data in an automated assessment platform. The combination of CA and feedback loops can be illustrated in the diagram in Figure 2.

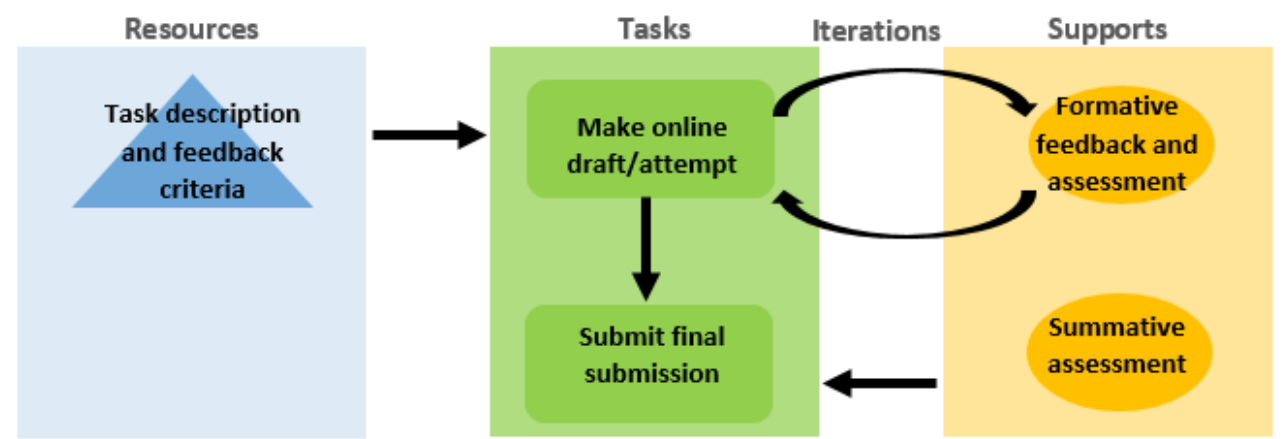

Source: Bjælde and Lindberg $(2018,54)$

Figure 2: Generic design combining feedback loops with continuous assessment 
The use of feedback and data on formative assessment not only leads to higher retention rates, but also makes student learning and progression visible to students and academics.

Sambell, Brown and Race (2019) highlight the importance of feedback literacy. Academics have a small window of opportunity at the beginning of the tuition period to familiarise students with their new academic environment. Lesson learned and literacies gained during this period have a direct impact on students' perceptions of CA.

For most academics and institutions the transfer to CA is a (steep) learning curve and this is reflected in the literature. A lack of knowledge of the principles of CA and a lack of proper planning invariably lead to failure. This was highlighted by Holcroft (2014) in his investigation of the (failed) implementation of CA by the Gauteng Department of Education in South Africa, and Abera, Kedir and Beyabeyin (2017) in their research on the implementation of CA in public universities in eastern Ethiopia. One can hear the desperation in the words of Walde $(2016,542-3)$ when he laments the state of CA at the Mettu University in Ethiopia:

There is also no systems to control its implementation, both instructors and students do not clearly understand the basic concepts of CA, due to this ... students . . cheat ... to score good mark on written test and also on group and individual assignment and hence it is difficult for instructors to know the students' difficulty. Some instructors have no positive attitude towards the implementation of CA due to lack of training, support and encouragements from university management.

This tragic state of affairs provides a learning opportunity for us in setting guidelines for the implementation of CA.

Coll et al. (2007) discuss the lessons learned and value added by introducing CA, using Moodle as the delivery platform. By organising and sequencing assessment activities around thematic blocks, they found that CA enhances learning and is "a well-suited instrument for fostering the attainment of learning" (Coll et al. 2007, 799). However, this positive outcome comes at the cost of an increased workload for staff members. The introduction of CA is a time-consuming and costly exercise where the bulk of the workload falls on academic staff and may require a revisit of the working conditions of academic staff (Coll et al. 2007, 800).

The studies referred to in this section help us to identify important issues that will affect the successful implementation of CA, which will be dealt with in the following sections. 


\section{The Importance of Feedback when Using Continuous Assessment for More Effective Learning}

We can distinguish the following functions of assessment:

- improve students' learning by focusing their attention on significant learning outcomes that have to be attained;

- provide feedback on the students' performance with regard to the specified learning outcomes; and

- provide feedback to the students on the way in which they can redress identified gaps in their knowledge and skills.

Formative assessment or assessment for learning will include all three these functions, whereas summative assessment will mainly focus on the first and second functions. To ensure that the first function can be attained, it is important that students be informed of and understand the learning outcomes that they have to achieve, and the way in which they can do this.

There are two parts to feedback. The first is the academic feedback that is provided to students to guide them regarding the reasons why the answers they provided are incorrect, and the actions that they can take to avoid similar mistakes in future. The second part of feedback has to do with the scoring, and the data that are generated by the answers provided by students. This can help students to monitor their performance over time, compare individual performance with the performance of the group as a whole, and also provide information to the teaching staff regarding the areas or assessments in which students need additional guidance.

Hatt $(2019,221)$ indicates that assessment can only be formative when feedback is provided that clearly indicates corrective action. This is why formative assessment is also referred to as assessment for learning. Timely information on the way in which students can improve their performance should motivate them to engage more effectively with their learning (Bjælde, Jørgensen, and Lindberg 2017, 4), contributing to deeper learning.

Students can also be asked to evaluate each other's work, and to provide feedback. Such a system enables students to put themselves in the shoes of the markers who have to do grading, and to develop a deeper understanding of what they are expected to do (Bjælde and Lindberg 2018,53). This improves learning and also teach students the valuable skill of providing constructive criticism (Russel et al. 2006, 473).

To ensure that feedback will support learning, the following requirements should be adhered to (Gibbs and Simpson 2004): 
- feedback should be of high quality and provide students with information on the way in which they can improve their learning and performance;

- feedback should be provided timeously, so that students can redress any gaps in their knowledge or abilities before they are assessed again;

- feedback should be received by the students and the students should understand in which way to use it; and

- students should attend to the feedback and should take active steps to redress the gaps in their performance effectively.

\section{Feedback in the Automated Online Assessment Environment}

Online automated assessment provides excellent opportunity for providing quick, efficient feedback for graded and non-graded assessment. This is an excellent tool that can be used effectively to indicate to students whether they have mastered specific sections of work before they proceed to a next step.

The advantage of online automated assessment is that individualised feedback can be provided with minimal effort by lecturers during the teaching period. This is especially important at institutions with large student numbers where cost and available workforce may limit the number of human graded assessments that can be included in a CA plan. Bjælde, Jørgensen and Lindberg $(2017,6)$ warn, however, that the design of assessment in a CA system should always focus on choosing assessment that encourages deeper learning, and that speed and lower cost should not be the deciding factors.

The possibility of using automated online assessment that incorporates individualised feedback and the type of scoring feedback that can be provided to students and lecturers are dependent on the learning management system that is used. It is important that such a system be easy to navigate for both lecturers and students, and should not involve computer coding to design effective feedback (Hatt 2019, 237). The choice of learning management system is therefore an important factor to consider when CA is introduced at an institution. Effective support to lecturers to help them when they experience problems with such a system is another important issue to consider when introducing automated online assessment and a CA system. In an education system where venuebased assessment is used, there are often administrative personnel who take responsibility for handling the administration of assessment. When automated online assessment is combined with a CA system, the responsibility of administration of the assessment system may be shifted to the lecturing staff. This can be an advantage, but can also place an additional burden on academic staff. 


\section{Potential Challenges when Employing Continuous Assessment in a Distance Education Framework}

The first important challenge is definitely the cost and time that need to go into the design and implementation of a CA system. Designing assessment with complete feedback so that students will be able to use their results and the feedback to improve their learning, is time consuming.

In a CA system, authentication of students can become an important challenge. If there is only one main examination, it is possible to have venue-based or online assessments that take place at a certain time, and where students' identities are authenticated. This becomes more difficult when there is a larger number of assessment tasks.

Both the challenge with regard to the cost and time that it takes to design and implement $\mathrm{CA}$ and the authentication of students are important factors to consider when taking decisions on the way in which CA will be implemented in an academic environment. However, these factors do not really affect learning, so let us turn now to the challenges of CA with regard to learning.

An important reason for using CA is that assessment which is mainly based on one final examination may cause stress and anxiety for students, owing to the high stakes related to this one assessment. However, if students feel that they are constantly assessed, this may also cause stress. The number of assessments and the complexity of assessment tasks should be balanced with the time that is available for learning and assessment (Bjælde, Jørgensen, and Lindberg 2017).

In the case of distance education, pacing of CA can become an important issue. Many students choose to engage in distance education because it provides the freedom to pace their own studies. CA may inhibit this freedom. It is therefore important that distance educators ensure that there is still adequate flexibility to satisfy students who choose the medium of distance education for this reason.

Students' attitude to and their understanding of the way in which CA works will also determine how effective CA will be to facilitate more effective learning. It is therefore necessary that students understand the way in which to use assessment results and feedback to identify and redress gaps in their learning.

Institutional support may also present a challenge for the implementation of CA. Belay and Tesfaye $(2017,62-3)$ found that deficient teaching-learning facilities was a significant challenge that affected the effectiveness of CA at Dire Dawa University in Ethiopia. Such facilities can include a lack of access to the internet, downtime of the learning management system, inadequate access to library resources and laboratory facilities, and other institutional factors that may hinder students to complete assessment tasks, submit assessment and receive feedback. 
It is important to take note of potential challenges related to CA and to plan the introduction of CA so that foreseeable problems may be avoided. It is also important that the time and cost to implement CA be carefully considered before introducing it, and the potential problems with regard to authentication of students.

\section{A Model for Introducing a Continuous Assessment Framework in an Academic Programme}

\section{Aspects to Consider when Introducing a CA Framework in an Academic Department}

The foregoing discussion indicates that there are several factors that should be considered when a CA framework is introduced in an academic department or programme. The following important aspects have been identified in the literature:

- providing training to academic and support personnel;

- choosing or designing an appropriate CA framework;

- considering the following management decisions:

- cost and time of design and implementation of CA;

○ cost and time involved with provision of feedback; and

○ adequate support personnel;

- educational experts providing support; and

- providing information on the assessment system to students.

\section{A Proposed Model to Introduce CA Framework in an Academic Department}

Smit $(2008,178)$ indicates that the most important obstacle to the successful implementation of CA in an academic institution is the inadequate management of the process, which can result in "work overload for both staff and students" (Smit 2008,178 ) and inadequate administrative support, both from the institution and in the department. It is therefore necessary to have a workable model in place to ensure that CA can be introduced effectively and that the advantages of CA for more effective learning can come to pass.

Figure 3 illustrates a model that can be helpful to plan the introduction of CA, and Table 1 summarises all the factors that can affect each of the environments shown in the model in Figure 3. 


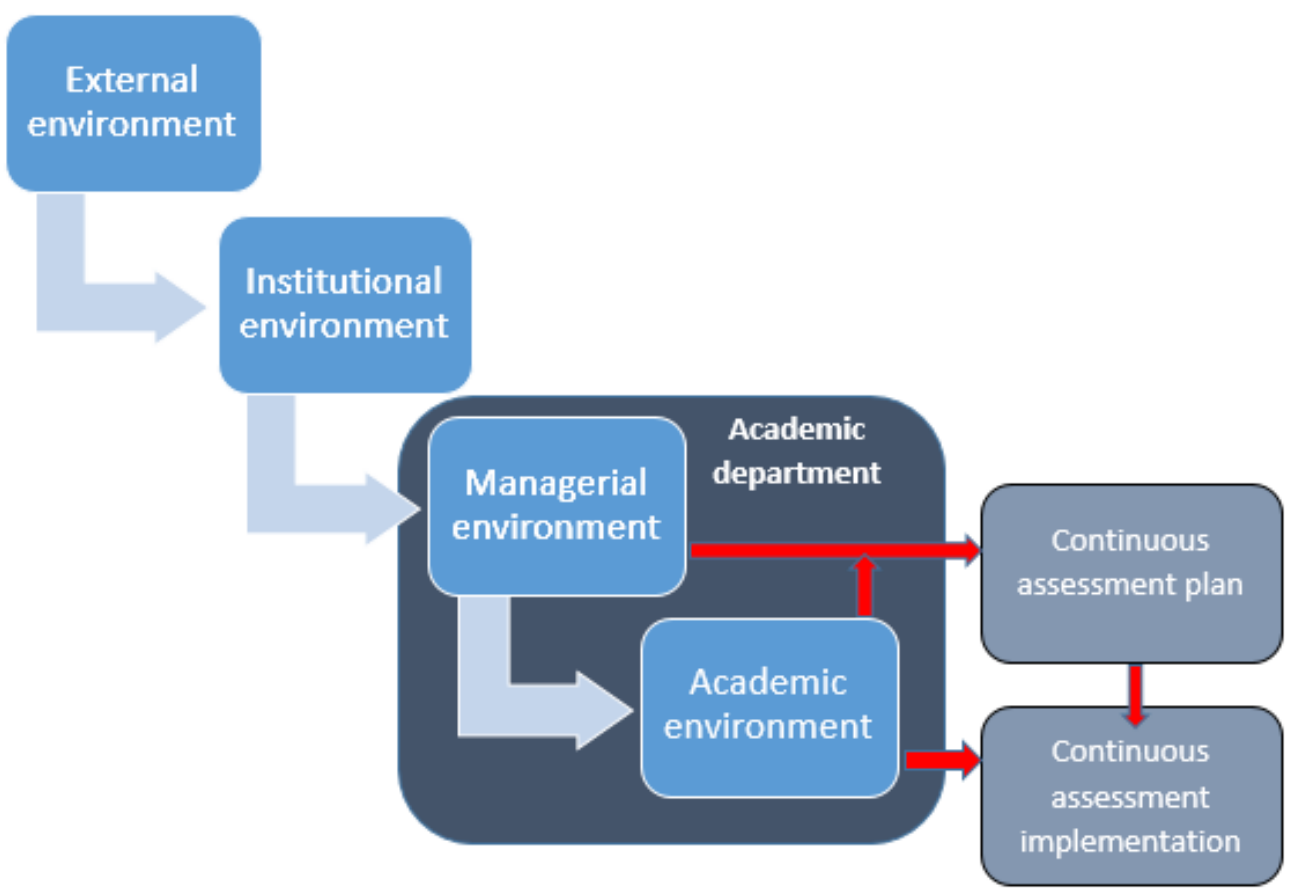

Figure 3: A model for the introduction of continuous assessment in an academic department

Table 1: Factors affecting environments that affect the implementation of continuous assessment

\begin{tabular}{|c|c|c|c|}
\hline \multirow{2}{*}{$\begin{array}{l}\text { External } \\
\text { environment }\end{array}$} & \multirow{2}{*}{$\begin{array}{l}\text { Institutional } \\
\text { environment }\end{array}$} & \multicolumn{2}{|c|}{ Departmental environment } \\
\hline & & $\begin{array}{l}\text { Managerial and } \\
\text { support } \\
\text { environment }\end{array}$ & $\begin{array}{l}\text { Academic } \\
\text { environment }\end{array}$ \\
\hline $\begin{array}{l}\text { Government } \\
\text { regulation } \\
\text { External } \\
\text { regulating bodies }\end{array}$ & $\begin{array}{l}\text { Institutional policy } \\
\text { Institutional planning } \\
\text { and funding } \\
\text { procedures } \\
\text { Learning } \\
\text { management system } \\
\text { ICT support } \\
\text { Instructional } \\
\text { design/educational } \\
\text { expertise support }\end{array}$ & $\begin{array}{l}\text { Departmental } \\
\text { culture } \\
\text { Characteristics of } \\
\text { support staff in the } \\
\text { department } \\
\text { Quality assurance } \\
\text { procedures } \\
\text { Planning and } \\
\text { funding } \\
\text { procedures } \\
\text { Performance } \\
\text { management }\end{array}$ & $\begin{array}{l}\text { Characteristics of } \\
\text { lecturers } \\
\text { Characteristics of } \\
\text { students } \\
\text { Programme } \\
\text { content and } \\
\text { programme design } \\
\text { Module content } \\
\text { and module design } \\
\text { Time allocated to } \\
\text { module }\end{array}$ \\
\hline
\end{tabular}


When CA is introduced in an academic environment, we can assume that government regulation and appropriate institutional policy allow for the introduction of such a framework. However, before CA is implemented it may be necessary to take cognisance of the requirements of any external regulating bodies, such as professional bodies, which may have certain requirements with regard to assessment of modules or programmes.

When the introduction of $\mathrm{CA}$ is driven by academics in a specific department or departments, it may be necessary to first investigate if institutional planning, the learning managements system and the ICT system, educational support and the available financial resources can support the introduction of such a framework. If the institution is driving the introduction of a CA framework in an institution as a whole (thus a top-down process), it may still be necessary to determine exactly in which way all these elements will support the introduction of CA.

The managerial and support environment in an academic department can play a determining role in the successful implementation of a CA framework. The upward arrow in Figure 3, from the academic environment towards the arrow that runs from departmental management towards the CA plan, illustrates that planning by departmental management in an academic department should be done in consultation with academics.

Quality assurance procedures, such as moderation of assessment, play an important role in any assessment system. The departmental management will have to consider that since CA implies more regular assessment activity, it may also imply more regular moderation activity.

Finally, there are several academic factors that will affect the introduction of a CA framework. Academic personnel should have an interest to learn about CA and the way in which it can improve learning, and should be enthusiastic about the implementation. The characteristics of the students also have to be considered. A CA framework may require students to have regular access to the internet as it will usually be implemented via an online learning management system.

Programme and module content and the way in which programmes and/or modules are designed are important factors to consider in the design of a CA system. Related to this issue is the matter of time management. Academic programmes and modules are designed to be completed in a certain limited number of hours, meaning that additional assessment activities cannot just be added to the programme or module.

Finally, Figure 3 illustrates that CA is implemented by academics. Despite all the other factors that may play a role and affect the implementation of a CA framework, the 
successful implementation mainly depends on the inputs, interest and didactic understanding of the lecturing team.

Table 2 provides an action list, based on the model discussed in this section, which can be used to plan the introduction a CA framework in an academic department. The action list for the training, design and implementation of a CA framework is provided in Table 3.

Table 2: Action list for planning the introduction of continuous assessment in an academic department

\begin{tabular}{|c|c|}
\hline $\begin{array}{l}\text { Item } \\
\#\end{array}$ & Description \\
\hline 1 & Set up steering committee responsible for introducing CA \\
\hline 2 & Determine external environment that affects introduction of CA \\
\hline 2.1 & Government regulation \\
\hline 2.2 & Regulation by relevant external bodies \\
\hline 3 & Determine institutional environment that affects introduction of CA \\
\hline 3.1 & Relevant institutional policy, e.g. assessment policy, tuition policy \\
\hline 3.2 & $\begin{array}{l}\text { Determine relevant institutional planning and funding procedures, and } \\
\text { appoint contact persons to arrange for planning and funding }\end{array}$ \\
\hline 3.3 & $\begin{array}{l}\text { Relevant aspects with regard to the learning management system (LMS), } \\
\text { e.g. which types of assessment can be accommodated, record-keeping in the } \\
\text { LMS }\end{array}$ \\
\hline 3.4 & Determine available ICT support and appoint contact persons \\
\hline 3.5 & $\begin{array}{l}\text { Determine available instructional design/educational expertise support and } \\
\text { appoint contact persons }\end{array}$ \\
\hline 4 & $\begin{array}{l}\text { Determine departmental managerial and support environment, } \\
\text { establish which steps are needed to enable the successful introduction of } \\
\text { CA and the way in which these will be implemented }\end{array}$ \\
\hline 4.1 & $\begin{array}{l}\text { Determine departmental culture regarding tuition and introduction of new } \\
\text { academic frameworks }\end{array}$ \\
\hline 4.2 & $\begin{array}{l}\text { Determine characteristics of support staff regarding ability and willingness } \\
\text { to help with support of CA framework }\end{array}$ \\
\hline 4.3 & Determine quality assurance procedures and whether these will support CA \\
\hline 4.4 & $\begin{array}{l}\text { Determine planning and funding procedures and the way in which these will } \\
\text { accommodate the introduction of a CA framework }\end{array}$ \\
\hline 4.5 & $\begin{array}{l}\text { Determine performance management procedures and the way in which } \\
\text { these can accommodate the introduction of a CA framework }\end{array}$ \\
\hline 5 & $\begin{array}{l}\text { Determine the current academic environment and the steps that are } \\
\text { required to enable the successful implementation of a CA framework }\end{array}$ \\
\hline 5.1 & $\begin{array}{l}\text { Determine characteristics of lecturers and the training that may be required } \\
\text { to enable lecturers to introduce CA in academic modules and programmes } \\
\text { to enable more effective learning }\end{array}$ \\
\hline
\end{tabular}




\begin{tabular}{|l|l|}
\hline $\begin{array}{l}\text { Item } \\
\#\end{array}$ & Description \\
\hline 5.2 & $\begin{array}{l}\text { Determine characteristics of students and the steps that will be taken to } \\
\text { inform them of the way in which a CA framework will work, the } \\
\text { advantages of such a framework and what is expected from them with } \\
\text { regard to CA to enable more effective learning }\end{array}$ \\
\hline 5.3 & $\begin{array}{l}\text { Evaluate current programme content and design, including the time } \\
\text { available to complete a programme, to determine if and in which way these } \\
\text { have to be adjusted to use CA for more effective learning }\end{array}$ \\
\hline 5.4 & $\begin{array}{l}\text { Evaluate module content and design, including the time available to } \\
\text { complete a module, to determine if and in which way these have to be } \\
\text { adjusted to use CA for more effective learning }\end{array}$ \\
\hline
\end{tabular}

Table 3: Action list for training, design and implementation of continuous assessment in an academic department

\begin{tabular}{|l|l|}
\hline $\begin{array}{l}\text { Item } \\
\#\end{array}$ & Description \\
\hline 1 & $\begin{array}{l}\text { Workshop/meeting to discuss the introduction of CA in the academic } \\
\text { department }\end{array}$ \\
\hline 1.1 & $\begin{array}{l}\text { Ensure all personnel understand terminology and principles of CA and the } \\
\text { implications of the introduction of CA }\end{array}$ \\
\hline 2 & $\begin{array}{l}\text { Draw up schedule that allows adequate time for training of relevant } \\
\text { personnel and for designing and implementing CA }\end{array}$ \\
\hline 3 & $\begin{array}{l}\text { Recruit and appoint personnel that may be required to help with } \\
\text { training, designing and implementing CA }\end{array}$ \\
\hline 4 & Training \\
\hline 4.1 & Training of support personnel \\
\hline 4.2 & Training of academic personnel \\
\hline 5 & Design of CA framework for department \\
\hline 5.1 & Adjustment of design of academic programme to include CA (if required) \\
\hline 5.2 & $\begin{array}{l}\text { Adjustment of design of academic modules to include CA that will ensure } \\
\text { more effective learning (if required) }\end{array}$ \\
\hline 5.3 & Design of CA plan for each module \\
\hline 5.4 & Design of quality assurance procedures to accommodate CA \\
\hline 6 & Implement CA framework \\
\hline 6.1 & $\begin{array}{l}\text { Set up assessment activities for each module that will enable more effective } \\
\text { learning, including appropriate feedback and marking guidelines }\end{array}$ \\
\hline 6.2 & Do quality assurance of assessment activities and assessment plan \\
\hline 6.3 & $\begin{array}{l}\text { Compile guidelines to inform students of the way in which the CA will } \\
\text { operate, why it is being introduced and what is expected from them }\end{array}$ \\
\hline 7 & $\begin{array}{l}\text { Evaluate and improve the CA framework for each department and the } \\
\text { institution as a whole }\end{array}$ \\
\hline
\end{tabular}




\section{Conclusions and Suggestions for Further Research}

Introducing a CA framework in an academic department can be expected to contribute to more effective learning, and ensure higher student success rates and retention rates. However, it is a time-consuming and costly exercise, and many factors may hinder successful implementation. It is therefore necessary to do a thorough investigation of the environment in which it will be implemented, and to plan the implementation carefully. The actions lists provided in Tables 2 and 3 should ensure that all factors that need to be investigated and planned, are considered. It is important to note that although CA does not necessarily imply that summative assessment is excluded, it may require a complete overhaul of the assessment system in an academic department and a different way of thinking about the reasons for assessment. More research is necessary to determine the way in which the advantages of CA can be measured, and the way in which quality assurance may be implemented in a CA framework.

\section{References}

Abera, G., M. Kedir, and M. Beyabeyin. 2017. "The Implementations and Challenges of Continuous Assessment in Public Universities of Eastern Ethiopia." International Journal of Instruction 10 (4): 109-28. https://doi.org/10.12973/iji.2017.1047a.

Baird, J., D. N. Andrich, T. N. Hopfenbeck, and G. Stobart. 2017. “Assessment and Learning: Fields Apart?" Assessment in Education: Principles, Policy and Practice 24 (3): 317-50. https://doi.org/10.1080/0969594X.2017.1319337.

Belay, S., and A. Tesfaye. 2017. "The Impending Challenges of Continuous Assessment Implementation at Dire Dawa University, Ethiopia." International Journal of African and Asian Studies 35: 59-68. https://www.researchgate.net/profile/Sintayehu-

Belay/publication/318491592_The_Impending_Challenges_of_Continuous_Assessment_I mplementation_at_Dire_Dawa_University_Ethiopia/links/596da9d40f7e9b81444168c5/Th e-Impending-Challenges-of-Continuous-Assessment-Implementation-at-Dire-DawaUniversity-Ethiopia.pdf.

Bjælde, O. E., T. V. Jørgensen, and A. B. Lindberg. 2017. "Continuous Assessment in Higher Education in Denmark: Early Experiences from Two Science Courses." Dansk Universitetspcedagogisk Tidsskrift 12 (23): 1-10. https://tidsskrift.dk/dut/article/view/25634/145813.

Bjælde, O. E., and A. B. Lindberg. 2018. "Using Continuous Assessment with Feedback Loops to Generate Useful Data for Learning Analytics." Open Oceans: Learning Without Borders 53. https://researchrepository.murdoch.edu.au/id/eprint/59155/1/ASCILITE-2018Proceedings-Final.pdf\#page $=55$. 
Coll, C., M. Rochera, R. Mayordomo, and M. Naranjo. 2007. "Continuous Assessment and Support for Learning: An Experience in Educational Innovation with ICT Support in Higher Education.” Electronic Journal of Research in Educational Psychology 5. https://www.researchgate.net/publication/228682597_Continuous_assessment_and_suppor t_for_learning_An_experience_in_educational_innovation_with_ICT_support_in_higher_ education.

Cook, L., D. Butler, and S. Jordan. 2013. "Student Engagement in Formative Assessment." Exploring the frontiers of STEM education. https://www.open.ac.uk/about/teaching-andlearning/esteem/sites/www.open.ac.uk.about.teaching-andlearning.esteem/files/files/ecms/web-content/2013-06-Sally-Jordan-AHEC-poster.pdf.

Gibbs, G., and C. Simpson. 2004. "Does Your Assessment Support Your Students' Learning?” Learning and Teaching in Higher Education 1 (1): 1-31.

Hatt, J. 2019. “Dynamic, Online, Objective Assessment for Continuous Assessment.” In The Handbook of Research on E-Assessment in Higher Education, edited by A. Azevedo and J. Azevedo. Hershey: IGI Global. https://doi.org/10.4018/978-1-5225-5936-8.ch009.

Hernández, R. 2012. "Does Continuous Assessment in Higher Education Support Student Learning?" Higher Education 64: 489-502. https://doi.org/10.1007/s10734-012-9506-7.

Holcroft, E. O. 2014. "Theory and Practice in Continuous Assessment: A Discussion of an Exemplar of CASS Practice in a Johannesburg Secondary School, in the Light of a Paradigm Shift in the Official Perspective on Assessment." Master's thesis, University of the Witwatersrand. http://hdl.handle.net10539/14525.

Lovatt, J., O. E. Finlayson, and P. James. 2007. "Evaluation of Student Engagement with Two Learning Supports in the Teaching of 1st Year Undergraduate Chemistry." Chemistry Education Research and Practice 8 (4): 390-402. https://doi.org/10.1039/B6RP90038K.

Pocock, J. 2012. "Leaving Rates and Reasons for Leaving in an Engineering Faculty in South Africa: A Case Study." South African Journal of Science 18 (3/4): 1-8. https://doi.org/10.4102/sajs.v108i3/4.634.

Ramsden, P. 2003. Learning to Teach in Higher Education. Abingdon: Routledge. https://doi.org/10.4324/9780203507711.

Russell, R., L. Elton, D. Swinglehurst, and T. Greenhalgh. 2006. "Using the Online Environment in Assessment for Learning: A Case-Study of a Web-Based Course in Primary Care." Assessment and Evaluation in Higher Education 31 (4): 465-78. https://doi.org/10.1080/02602930600679209.

Sambell, K., S. Brown, and P. Race. 2019. “Assessment as a Locus for Engagement: Priorities and Practicalities." Italian Journal of Educational Research 45-62. https://ojs.pensamultimedia.it/index.php/sird/article/view/3268. 
Siemens, G. 2005. "Connectivism: A Learning Theory for the Digital Age." International Journal of Instructional Technology and Distance Learning 2 (1).

https://lidtfoundations.pressbooks.com/chapter/connectivism-a-learning-theory-for-thedigital-age/.

Smit, J. J. A. C. 2008. "A Conceptual Model for the Management of the Implementation of a Continuous Assessment Plan at a University of Technology." PhD thesis, North-West University. http://repository.nwu.ac.za/handle/10394/1781.

Thorpe, M. 1998. “Assessment and 'Third Generation' Distance Education.” Distance Education 19 (2): 265-86. https://doi.org/10.1080/0158791980190206.

Walde, G. S. 2016. "Assessment of the Implementation of Continuous Assessment: The Case of METTU University." European Journal of Science and Mathematics Education 4 (4): 534-44. https://doi.org/10.30935/scimath/9492. 